\title{
Higher EduCATION FACULTY STAFF E- READINESS IN INSTITUTIONS OF THE ROYAL COMMISSION IN JUBAIL
}

\author{
Mohamed Elsaadani ${ }^{1}$ and Saleh Alzahrani ${ }^{2}$ \\ ${ }^{1 \& 2}$ Assistant Professor, Jubail University College, Royal Commission in \\ Jubail, Jubail Industrial City, Kingdom of Saudi Arabia. \\ ${ }^{1}$ Assistant Professor, the Arab Academy for Science \& Technology \& Maritime \\ Transport, Alexandria, Egypt.
}

\begin{abstract}
Critical analysis of technological skills deemed extremely important in the evaluation of faculty staff $e$-readiness. Research aims at assessing e-readiness of faculty staff in the affiliate institutions of the Royal Commission in Jubail, and to investigate whether their experience in using ICTs influences their judgement about using ICTs or not. Survey methodology facilitated through the use of questionnaires collected from 146 respondents. Analysis revealed that faculty staff judgement about using ICTs, their e-readiness and willingness to using ICTs are highly positive. Moreover, their experience in using ICTs did not significantly predict their judgement about ICTs. The result of this study provides valuable insights as it will enable policy-makers to prioritize interventions needed for transforming the Institutions of the Royal Commission in Jubail into an e-ready entity favourably placed to benefit from digital opportunities, as well as to develop and support factors that enhance strategies for adopting ICTs effectively.
\end{abstract}

\section{KEYWORDS}

E-readiness, ICTs, experience, judgment, HEIs

\section{INTRODUCTION}

Researchers have come to an apparent conclusion that the adoption of ICTs creates a competitive advantage, as it is obvious that global advancements in ICTs have led to the emergence of global economies driven by knowledge [1]. Involvement in these global economies needs organizations to be e-ready in order to harness various digital opportunities [2].

It was reported that the most common obstacle for HEIs in adopting ICTs is establishing the environment that supports the effective use of ICTs [3]. Moreover, it was reported that there are some other aspects that may delay the overall success of ICTs adoption, such as institutional, social and economic factors [4]. 
International Journal of Advanced Information Technology (IJAIT) Vol. 8, No.3, June 2018

The demand for e-learning approaches is currently advancing along with the advancement in various ICTs [5]. These advancements will pave way for the use of ICTs in teaching and learning, but this requires a special preparation for faculty staff including, and not limited to, managerial and technical training $[6,7]$.

Many HEIs are rapidly adopting recent ICTs, especially e-learning platforms in order to gain competitive advantages $[8,9]$, as well as to ensure the reduction of the space and time boundaries in their activities to increase the interaction between HEIs stakeholders $[10,11]$.

The majority of prior studies studied ICTs with a major focus on students $[12,13]$, and a few studies were focused on faculty members [14]. This gives importance to the study on hand, as it will fill the gap of the lack of empirical evidence regarding faculty staff e-readiness especially in the developing countries, thus contributing to theory and practice by proposing a contextaware conceptual framework for appropriate measurement of e-readiness in a developing world HEIs context. Moreover, $[15,16]$ has declared that assessing faculty e-readiness especially in Business study is a more promising area of evaluation, as research stream regarding e-learning has much been done, but the investigation into e-readiness of the users themselves has been very little. This represents one major motive to accomplish that research.

\section{ICTS IN HEIS}

Using ICTs in teaching and learning has become a well-known and common phenomenon in higher education [17]. As the use of ICTs is increasing worldwide, ICTs have changed lives in general than it was before, and as a consequence changed HEIs dramatically. ICTs provide HEIs with a new educational environment that is capable of changing lives of both faculty and students [18], as well as enhancing speed and quality of teaching and learning process [19].

Educational technologies are becoming more and more prevalent in the education management. ICTs have changed HEIs to become more space and time flexible than traditional modes of study; increasing the accessibility, flexibility, and choices for interactivity [20]. Alzahrani [21] declares that using ICTs in education has overcome the historical limitations of traditional teaching and learning environments; thus enhancing education profession to be more interactive, challenging, and situated.

HEIs utilizes ICTs in three different methodologies. They can use ICTs in delivering online education, or they can enhance traditional teaching by mixing it with e-learning technologies, such as using "blended" teaching methodology, or they can supplement traditional teaching with e-learning technologies, such as using LMSs as a repository for course materials [22].

The majority of faculty staff had different levels of positive points of view regarding using ICTs in teaching and learning. Yazon et al. [23] declared that some faculty staff are using ICTs as a supplementary tools in their classrooms in addition to using other traditional teaching and learning tools. Katz and Yablon [24], in the same context, declared that some faculty members are using ICTs as a communication tool to interact with students and to deliver learning resources to them, while following the traditional methods as their primary teaching and learning approaches. Palloff and Pratt [25] declared that other faculty staff members are using ICTs in their teaching and learning heavily as they believe that these ICTs will result in creating high quality teaching and learning results. 
International Journal of Advanced Information Technology (IJAIT) Vol. 8, No.3, June 2018

On the other hand, some authors are not in favor of using ICTs in teaching and learning environment. Conlon [26] has mentioned that technologies do not solve modern learning problems and difficulties, Gallick, on the other hand, stated that technology may reduce standards or even devalue the social point of view regarding university degrees [27], Twigg declared that students may not be able to find quality learning resources [28], and Weiger mentioned that it will be hard to ensure the quality of faculty staff members [29].

\section{FAculty E-REadiness}

E-readiness was defined as being built to join people, processes and technologies. Also, it necessitates the availability of essential ICT infrastructure and users' ability to use such technologies [30]. Moreover, [31, 32] has defined e-readiness as the level of readiness and the capability in using a new technological learning environment

[33] Has further declares that assessing e-readiness is very important and is considered as a base for the planning of ICTs resources in HEIs, and it is very important to provide an ongoing mechanism that supports faculty staff with the required issues in the e-learning environment both managerially and technically.

Authors examined faculty readiness through the investigation of many factors such as technical skills, access to technology, motivation, attitude, personal characteristics, self-directed learning, online skills, online communication, learner control, and time management [34, 35]. The main challenge that was determined in the assessment of faculty readiness is their e-readiness $[36,37$, $38,39]$.

In the same context, Zinn [40] declared that the most important issue is the e-readiness of faculty due to the fact that ICT revolution started to impact the way higher education is delivered, and as e-learning is evolving as an innovative mode of learning delivery.

Agboola [41] has assessed the academic staff e-readiness level of the implementation of elearning. He discovered that training and confidence affected e-readiness. Moreover, the gender of the respondents doesn't have any effect at all on e-readiness.

Volery and Lord [42] assessed three main criteria that impact faculty e-readiness: competences, attitudes, and experiences. The current research is sought to adopt the assessment of faculty staff e-readiness using the experiences aspect, as the other two aspects were previously investigated and widely researched [30].

Watkins and Corry [43] have questioned the effectiveness of the use of the e-learning environment. They indicated that it is appropriate to conduct an e-readiness assessment before the adoption of an e-learning environment. This exact opinion was shared by $[15,16]$. Complementing on that, Ilhan and Cetin [35] detailed e-readiness aspects in the following issues: attitude towards online learning, the quality of the internet and computer technologies used within the online learning process, the perceived ease of use, and technical skills.

Bui and Sebastian have explained the importance of e-readiness assessment as it provides indicators which can guide policy-makers with regards to which ICTs investments needs to be done in order for organizations to become competitive. Moreover, this assessment allow organizations to examine their ability to integrate ICTs in their business processes to achieve 
International Journal of Advanced Information Technology (IJAIT) Vol. 8, No.3, June 2018

efficiency and effectiveness [44]. Moreover, Chipembele and Bwalya showed that e-readiness is based on the evidence that integration of ICTs in business processes will result in having an organization that harnesses the digital opportunities that come from participating in ICTs society [45]. In the same context, authors declared that high faculty e-readiness will result in gaining ability to communicate and disseminate information on-line [46], using tools that support and help to improve teaching and learning activities [47], achieving high ability to motivate and interest students, and using learning systems that provide greater flexibility [48].

\section{ReSEARCh ObJeCtive}

An interest in this topic developed as a result of personal observation of several failures and the loss of interest in ICT implementation by some faculty.

This research aims at investigating e-readiness of the faculty staff in the affiliate Institutions of the Royal Commission in Jubail - Jubail University College (JUC), Jubail Industrial College (JIC), and Jubail Technical Institute (JTI) - and whether their experience in using ICTs influences their judgement. This research results will aid HEIs in promoting the use of ICTs in teaching and learning, also it will aid in preparing more qualified and skilled graduates. This research seeks to assess e-readiness through discovering faculty experiences, use and judgement towards ICTs, and whether their judgement and experience toward ICTs influence their use of ICTs or not.

\section{Methodology}

This paper draws on the academic year 2016-2017 at HEIs of the Royal Commission in Jubail.

The current research seeks to assess faculty e-readiness through investigating their use, experiences, and judgements about ICTs. So, in the context of this research, e-readiness involves the ability and capacity of JUC, JIC, and JTI faculty to integrate ICTs in their teaching and learning activities.

As there is no need to control faculty behavioral activities, and due to focusing only on current events for adopting ICTs, thus, the appropriate research strategy is to use the survey, which was conducted to determine:

1. What relationships exist between faculty demographics (i.e., age, marital status, working department, academic rank, years served as a teacher, accessibility to computer and internet at office and home, and finally, training hours received related to using ICTs in education) and the main survey constructs?

2. What experiences in ICTs does faculty staff had?

3. To what extent do faculty staff use ICTs in their teaching activities?

4. What judgement do faculty staff have towards using ICTs in their teaching activities?

The instrument was tested in order to ensure that the questions used reflect the intended meaning of the researcher and to ensure that this meaning will be understood by anyone reading these questions, thus increasing the instrument validity. The instrument was piloted in two distinct ways. First, as part of the design and validation of the instrument, a pilot version of the instrument 
International Journal of Advanced Information Technology (IJAIT) Vol. 8, No.3, June 2018

was sent to 30 faculty members in JUC, JIC, and JTI, who were experienced in research as well as teaching and were known to be significantly involved in using ICTs in their teaching. This proved to be a helpful exercise prior to the pilot study as some significant suggestions were made which called for several modifications. Secondly, a follow-up pilot study initiative involved a sample of faculty from JUC, JIC, and JTI. This pilot study sample comprised 15 Faculty staff, with a return rate of $100 \%$. The responses from this pilot sample did not request any further modifications to the instrument.

The population for this study is comprised of 669 full-time faculty staff in the affiliate Institutions of the Royal Commission in Jubail. While the random sample is 146 faculty staff members representing $20 \%$ of the population.

When an instrument is accurate and consistent, it is supposed to have a high degree of reliability [49]. According to a Cronbach Alpha, reliability for the used instrument was $92 \%$ for pilot data, while it was $93.1 \%$ for the instrument collected data, which reflects an acceptable levels of reliability for the survey instrument.

The instrument was designed to collect information relevant to experiences, use, and judgement aspects of ICTs. The ideas for instruments that were used in this study were adopted and modified from the literature reviews of previous studies [50, 51, 52].

Minges presented some of the common models and frameworks for assessing e-readiness [53]. The "World Economic Forum NRI" model is one of these models, which comprises three components: environment readiness, readiness to access ICTs and ICTs use. For the purposes of this study, it is worth mentioning that the NRI is much closer to the current study objectives as it focuses of ICTs access and use. Thus, this study uses a modified NRI framework which is the most widely used in HEIs for assessing e-readiness compared to other models [54, 55].

Each one of the four constructs in the instrument had an accompanying measures/scales as follows:

1.Demographic information: This construct collects information regarding working institution, age, marital status, working department, highest degree obtained, academic rank, years of teaching experience, accessibility to computer and internet at office and home, and finally training hours received related to using ICT in education.

2. Experience with ICTs: 5-point Likert-type Scale as follows: 1 for "No Experience", 2 for "Below Average Experience", 3 for "Average Experience", 4 for "Above Average Experience", and 5 for "Expert".

3. Use of ICTs in teaching and learning: 5-point Likert-Type Scale starts from 1 for "never", 2 for "rarely", 3 for "occasionally", 4 for "frequently", and 5 for "always".

4. Judgement about ICTs use: the scale asks participants to place an "X" at the point on the scale that agrees with his/her best judgment about the use of ICTs in his/her teaching on a five point scale. The scale is categorized by several bi-polar adjectives.

Statistical Package for Social Science (SPSS) program version 19 used in coding and analyzing data. The probability level for a test of statistical significance for the study is $p<.05$, to ensure a 95\% confidence in generalization of the findings. 
International Journal of Advanced Information Technology (IJAIT) Vol. 8, No.3, June 2018

\section{Analysis AND Results}

The test of normality of questionnaire data (PP plot), reliability test (Cronbach alpha), descriptive analysis, T-test, one-way analysis of variance (ANOVA), correlation analysis, regression analysis, and univariate analysis of variance (F-test) were used in analyzing both pilot and the collected data. The descriptive analysis was employed in order to determine the frequencies, means, and standard deviations for dependent and independent variables. The Ttest was employed in order to determine if means of two sets of scores are significantly different from each other or not. One-way ANOVA was employed in order to determine whether several sets of scores have different means or not. The correlation and multiple regression analysis was employed in order to determine the relationships among dependent and independent variables. The correlation was also used with piloted data in order to ensure the criterion and construct validity. The univariate analysis of variance was employed in order to see whether changes in the independent variables have significant effects on the dependent variable, and to discover interactions among independent variables and associations between dependent variables, if any. Cronbach alpha was used with both the piloted and the final version of the instrument in order to ensure that the instrument is reliable. A test of normality was conducted at the beginning in order to determine whether random variables were normally distributed or not, since this enhances the application of statistical tests applicable to normal distribution variables. The probability level for all tests of statistical significance for the study was set at $\mathrm{p}<0.05$. Highest level of education, working institution and department were treated as categorical variables.

\subsection{ANALYSIS OF DEMOGRAPHIC INFORMATION DEMOGRAPHIC INFORMATION}

Demographic information collected includes working institution, age, marital status, working department, highest degree obtained, academic rank, years of teaching experience, accessibility to computer and internet at office and home, and finally training hours received related to using ICTs in education.

Participants' demographics were tabulated by frequency and percentage as follows:

- Working institution: Sixty nine (47\%) respondents from JUC, thirty three (33\%) respondents from JIC, and the remaining $29(20 \%)$ are respondents from JTI.

- $\quad$ Gender: One hundred twenty four $(85 \%)$ respondents are males. The remaining twenty two (15\%) are female Faculty employed by the participating HEIs.

- $\quad$ Age: Participants' ages ranged from 20 to over 60 years old. The findings revealed that $12 \%$ of the respondents were between 20 and 30 years old. The respondents in the 30 to 40 age categories represented $28 \%$, while the respondents in the 40 to 50 age categories represented $34 \%$. The respondents in the 50 to 60 age categories represented $22 \%$, while the oldest respondents who were over 60 years old represented $6 \%$.

- $\quad$ Marital status: one hundred twenty seven (87\%) respondents married, while 19 (13\%) respondents single.

- Working departments: The findings revealed that $32(22 \%)$ of the respondents belong to General Studies department. Thirty nine $(27 \%)$ belong to English language department. Twenty nine $(20 \%)$ belong to Engineering departments. Fourteen (10\%) belong to Computer Science 
International Journal of Advanced Information Technology (IJAIT) Vol. 8, No.3, June 2018 department. Three (1\%) belong to Interior Design department. Fourteen (10\%) belong to Business Administration department. Fifteen (10\%) belong to other departments.

- $\quad$ Highest level of education: six (4\%) respondents had Diploma degree, 34 (23\%) respondents had Bachelor degrees, 61 (42\%) respondents had master degrees, and $45(31 \%)$ respondents had $\mathrm{PhD}$ degrees.

- Academic rank: two (1\%) respondents professors, 2 (1\%) respondents associate professors, $41(28 \%)$ respondents assistant professors, $43(29 \%)$ respondents lecturers, and 58 $(41 \%)$ respondents instructors.

- Years of higher education teaching experience: ten (7\%) respondents had Less than 2 years of higher education teaching experience, $22(15 \%)$ respondents have over 2 to 5 years of higher education teaching experience, 28 (19\%) respondents have over 5 to 10 years of higher education teaching experience, 28 (19\%) respondents have over 10 to 15 years of higher education teaching experience, $30(21 \%)$ respondents have over 15 to 20 years of higher education teaching experience, $28(19 \%)$ respondents have more than 20 years of higher education teaching experience.

- Having accessibility to computer at home: $136(93 \%)$ respondents reported that they access computers at home, while $10(7 \%)$ respondents reported that they don't access computers at home.

- $\quad$ Having accessibility to computer at work: 144 (99\%) respondents reported that they access computers at work, while $2(1 \%)$ respondents reported that they don't access computers at work

- $\quad$ Having accessibility to internet at home: $138(95 \%)$ respondents reported that they access internet at home, while $8(5 \%)$ respondents reported that they don't access internet at home.

- Having accessibility to internet at work: the complete 146 (100\%) respondents reported that they access internet at work.

- $\quad$ Attended any course or workshop related to using ICTs in education: 89 (61\%) respondents reported that they attended course and/or workshop related to using ICTs in education, while 57 (39\%) respondents reported that they didn't attended any course and/or workshop related to using ICTs in education.

The relationship between faculty demographics and demographics correlation with other questionnaire constructs examined using t-test, one-way ANOVA, and correlation.

One-way analysis of variance (ANOVA) revealed that there is a significant difference between the use of ICTs in teaching and learning with each of the following:

- Working department (sig. $=0.012)$,

- Academic rank (sig. = 0.003), $\square$ Age (sig. = 0.006),

- Years of teaching experience $($ sig. $=0.019)$, and 
International Journal of Advanced Information Technology (IJAIT) Vol. 8, No.3, June 2018

- Training received related to using ICTs in education (sig. $=0.005$ ).

In order to determine the "significant differences" between male and female faculty members and their general use of ICTs, t-test is used. The mean extent of ICTs use in general for male $(n=124)$ respondents and female $(n=22)$ respondents shows that there is no significant difference between the responses of male and female.

On the other hand, ANOVA revealed that there is no significant difference between the use of ICTs in teaching and learning and each of the following:

- Accessibility to computer at office (sig. $=0.135$ ),

- Accessibility to computer at home (sig. $=0.175)$,

- Accessibility to internet at office (sig. $=0.104)$, and

- Accessibility to internet at home (sig. $=0.118$ ).

Correlation coefficient between demographic variables revealed that years of teaching experience have a significant high positive correlation with the following demographic variables: academic rank, age, marital status, accessibility to computer and internet at office, and training hours received related to using ICTs in education, but it has a negative correlation with accessibility to computer and internet at home.

\subsection{EXPERIENCES WITH ICTS}

The general question on the experience with ICTs was introduced to respondents in the instrument after asking for information about their experience with different ICTs in their teaching in order to investigate their familiarity with ICTs in their teaching. Data results for this question reveal a skewed result toward high positive experience levels.

In response to the question about the experience with ICTs in teaching, the data reveals that, 41 of $146(28 \%)$ respondents reported "Expert" with ICTs in their teaching. $74(51 \%)$ reported that they had "above average experience", 23 (16\%) reported that they had "average experience", 7 (3\%) reported that they had "below average experience", and $3(1 \%)$ reported that they had "no experience" with ICTs in their teaching.

The experience with the item "Computer use in general" had the highest level mean score, followed by the experience with "e-mail programs", followed by the experience with "Microsoft office", followed by the experience with "learning management system", followed by the experience with "internet browsers", followed by "web searching", followed by the experience with "classroom support tools", followed by the experience with "operating systems", followed by the experience with "threaded discussion", and finally followed by with the least mean score was for the experience with "smart devices". While respondents reported that they had no experience with both "anti-plagiarism software" and "web-page creation".

\subsection{USE Of ICTS In TEACHING \& LEARNING}

The general question on the use of ICTs was introduced to respondents in the instrument after asking for information about their use of different ICTs in their teaching in order to investigate their various use degrees of ICTs in their teaching. The data results for this question reveal a skewed result toward high positive use degrees. 
International Journal of Advanced Information Technology (IJAIT) Vol. 8, No.3, June 2018

In response to the question about the use of ICTs in teaching, the data reveals that, 33 of 146 (23\%) respondents reported "always" using ICTs in their teaching. 62 (42\%) reported "frequently", 37 (25\%) reported "occasionally", 7 (5\%) reported "rarely", and 7 (5\%) reported "never" as their use degrees of ICTs in teaching.

The use of the item "presentation software" had the highest level mean score, then the use of "online resources", then the use of "internet", then the use of "e-mail", then the use of "scanning", and finally the least mean score was for the use of "online students discussion". While respondents reported that they had no experience with the use of "smart devices".

\subsection{Judgment About ICTS}

Use The judgement of faculty staff regarding the use of ICT in teaching is measured using a scale categorized by several bi-polar adjectives. There is a greatly skewed positive distribution in the opinions of the faculty's response regarding their judgement about using ICTs as they regarded it as fair (90\%), good (94\%), pleasant (89\%), encouraging (89\%), meaningful (94\%), and interesting $(89 \%)$.

The analysis of questionnaire's data showed that the overall judgement of faculty staff towards ICTs is positive $(M=5.21, S D=0.91)$. In order to discover whether faculty staff experience with ICTs is a predictor for their judgement about ICTs use, a multiple regression was conducted. The analysis showed that the experience with ICTs did not significantly predict faculty's judgement about ICTs use $(\mathrm{R} 2=0.263$, adjusted $\mathrm{R} 2=0.079, \mathrm{~F}=1.347, \mathrm{p}=0.171)$.

This result is consistent with $[52,56]$ who found that faculty members have a positive judgement about ICTs use in their case studies.

\section{CONCLUSION}

The current study assessed e-readiness of faculty staff in the affiliate institutions of the Royal Commission in Jubail through the investigation of their experiences, use, and judgement regarding ICTs. Also, it investigates whether faculty staff experience in using ICTs influences their judgement regarding ICTs or not. That result provides valuable insights into faculty ereadiness, as this information may be used to develop and support factors that effectively enhance future strategies for ICTs adoption to meet current and future needs.

It was discovered that the following set of ICTs requires the most attention in the future adoption planning by the Royal Commission for its three affiliate HEIs: "threaded discussion", "antiplagiarism software", "web-page creation", "online students discussion", and "smart devices". This set of ICTs receives the least scores of use and experience responses from study participants. Future adoption of these set of ICTs will not be a difficult mission as the overall results showed a positive faculty judgement about ICTs use, which reflect e-readiness and willingness to use ICTs.

The results of faculty staff responses are categorized in two trends. The first trend results are skewed towards the non-use and non-experience regarding the following set of ICTs: "antiplagiarism software", "web-page creation", "online students' discussion", and "smart devices". The following reasons can help in understanding the majority of these results: (1) The antiplagiarism software is not available for the faculty staff to use in their teaching activities, (2) The web-page creation is not mandatory for accomplishing teaching activities as faculty staff 
International Journal of Advanced Information Technology (IJAIT) Vol. 8, No.3, June 2018

don't have to design a special webpage to be accessed by their students, (3) The smart devices use is not a requirement for faculty staff to accomplish teaching activities.

The second trend represents skewed results towards the use of and the experience with the following set of ICTs: "e-mail programs", "Microsoft office", "presentation software", "learning management system", "internet", "web searching", "classroom support tools", "operating systems", "online resources", and "scanning". These results can be attributed to the following reasons: (1) book publishers distribute presentation slides made by the authors themselves for each book, which requires the use of presentation software in teaching these courses, (2) every book is accompanied by an information CD-ROM that holds course information and materials that aid in the teaching of this book, as well as online resources for that book, (3) Royal Commission in Jubail adopted "Blackboard" as a learning management systems available for faculty staff teaching in the affiliate HEIs, (4) HEIs equipped all classrooms and teaching halls with modern "classroom support tools", as well as Internet accessibility

\section{SigNificance OF RESEARCH}

The current study has yielded information on e-readiness of faculty staff by investigating their experiences, uses, and judgments about ICTs in teaching, therefore adding to the limited literature on ICTs in HEIs in the Saudi context. This up-to-date information is very significant to administrators of HEIs in the Kingdom of Saudi Arabia.

The results represent positive encouragement for faculty to use ICTs in teaching and learning activities. Moreover, the adopted survey instrument, which best suits the Saudi context and hence reflects the local faculty's characteristics, is more appropriate for use by researchers in the Kingdom of Saudi Arabia when investigating issues related to ICTs in HEIs, as this instrument does have its own statistical measures of reliability and validity.

\section{FUTURE RESEARCH}

The current research attempts to utilize a theoretical approach in an exploratory research area in order to reveal some findings. The following suggestions are recommended for future research studies based on these findings: (1) further research is necessary to address the limitations of the current study, since the research is limited only to a set group of available technologies within the domain of teaching in HEIs, it is highly recommended that further studies are conducted to adopt other sets of technologies, (2) further research is also recommended to include more case studies and to test other settings with other types of ICTs within other domains.

These recommendations will enhance the generalizability of current research findings and will add more validity and reliability.

\section{REFERENCES}

[1] Manyika J, Chui M, Bughin J, Dobbs R, Bisson P, \& Marrs A., (2013) "Disruptive technologies: advances that will transform life business and the global economy". Retrieved August 2, 2017 from www.mckinsey.com/insights/business_technology/disruptive_technologies.

[2] Lou E, \& Goulding J., (2010) "The pervasiveness of e-readiness in global built environment arena", Journal of Systems and Information Technology", Vol. 12, No. 3, pp 180-195. 
International Journal of Advanced Information Technology (IJAIT) Vol. 8, No.3, June 2018

[3] Shin J, \& Harman G., (2009) "New challenges for higher education: global and Asia-Pacific perspectives", Asia Pacific Education Review, Vol. 10, No. 1, pp 1-13.

[4] Ozdemir Z, \& Abrevaya J., (2007) "Adoption of technology-mediated distance education: a longitudinal analysis”, Information and Management, Vol. 44, No. 5, pp 467-477.

[5] Advisory Committee for Online Learning (2001) The E -learning e-revolution in colleges and universities, Executive Summary - A Pan-Canadian Challenge.

[6] Dikshit J, Gaba A, Bhushan S, Garg S, \& Panda S., (2003) "Learning Attitude, Motivation and Preferences of Online Learners", Indian journal of Open Learning, Vol. 12, No. 3, pp 149-167.

[7] Rohfeld R, \& Hiemstra R., (1995) "Moderating discussions in the electronic classroom", Computer mediated communication and the online classroom, Cresskill NJ: Hampton Press, Vol. 3, pp 91-104.

[8] Moolman H, \& Blignaut S., (2008) "Get set! e-Ready, e-Learn! The e-readiness of warehouse workers", Educational Technology and Society, Vol. 11, No. 1, pp 168-182.

[9] De Moraes M, Melo F, Oliver E, \& Cabral A., (2010) "Analysis of technological innovation strategy for small and medium companies of the aeronautical sector", Journal of AerospaceTechnology Management, Vol. 2, no. 2, pp 225-236.

[10] Rohayani A, \& Sharipuddin K., (2015) "A literature review: readiness factors to measuring e- learning readiness in higher education", Procedia Computer Science, Vol. 59, No. 1, pp 230-234.

[11] Kumpulainen K., (2007) Educational Technology: Opportunities and Challenges, Oulu University Press, Oulu.

[12] Lin W, \& Wang C., (2012) "Antecedents to continued intentions of adopting e-learning system in blended learning instruction: a contingency framework based models of information system success and technology fit", Computers \& Education, Vol. 58, No. 1, pp 88-99.

[13] Lee Y, Hsieh Y, \& Chen Y., (2013) “An investigation of employees' use of e- learning systems: applying the technology acceptance model", Behavior \& Information Technology, Vol. 32, No. 2, pp 173189.

[14] Islam A., (2011) "The determinants of the post-adoption satisfaction of educators with an e- learning system", Journal of Information Systems Education, Vol. 22, No. 4, pp 319-332.

[15] Kakoty S, Lal M, \& Sarma S., (2011) "E-learning as a Research Area: An Analytical Approach", (IJACSA) International Journal of Advanced Computer Science and Applications, Vol. 2, No. 9, pp 13-20.

[16] Kakoty S, \& Sarma S., (2011) "Expert System Applications in E-learning Environment: Analysis on Current Trends and Future Prospects", International Journal of Internet Computing (IJIC), Vol. 1, pp 90-93.

[17] Al-Busaidi K., (2013) “An empirical investigation linking learners' adoption of blended learning to their intention of full e-learning", Behavior \& Information Technology, Vol. 32, No. 11, pp 1168-1176.

[18] Tubaishat A, \& Lansari A., (2011) "Are Students Ready to Adopt E -Learning? A Preliminary Ereadiness Study of a University in the Gulf Region", International Journal of Information and Communication Technology Research, Vol. 1, No. 5, pp 210-215.

[19] Marquardt M, \& Kearsley G., (1999) Technology-based learning: Managing human performance and corporate success, Boca Raton, Florida: St. Lucie Press.

[20] Goyal E, \& Purohit S., (2010) "Study of Using Learning Management System in a Management Course", SIES Journal of Management, Vol. 6, No. 2, pp 11-20.

[21] Alzahrani S., (2012) "Assessment of learning at Jubail University College (JUC) using Information Technology (IT)", 5th International Conference of Education, Research and Innovation, November 19th 21st, Madrid, Spain. 
International Journal of Advanced Information Technology (IJAIT) Vol. 8, No.3, June 2018

[22] Islam A., (2012) Understanding e-learning system users' post-adoption usage behavior and its outcomes: a study of a learning management system, PhD Dissertation, Turku School of Economics, Turku.

[23] Yazon J, Mayer-Smith J, \&Redfield R., (2001) "Does the medium change the message? The impact of a web-based genetics course on university students' perspectives on learning and teaching", Computers \& Education, Vol. 38, No. 1-3, pp 267-285.

[24] Katz Y, \& Yablon Y., (2002) "Who is afraid of university Internet courses", Education Media International, Vol. 39, No. 1, pp 69-73.

[25] Palloff R, \& Pratt K., (2000) Making the transition: Helping teachers to teach online. EDUCAUSE: Thinking it through. Nashville, TN.

[26] Conlon R., (1997) "Whole mount in situ hybridization to embryos and embryonic tissues", Methods Mol. Biol., Vol. 63, pp 257-262.

[27] Gallick S., (1998) Technology in higher education: Opportunities and threats, University of California at Los Angeles, Los Angeles, CA.

[28] Twigg C., (2001) Quality assurance for whom? Providers and consumers in todays distributed learning environment, The Pew Learning and Technology Program, Center for Academic Transformation, Troy, New York.

[29] Weiger P., (1998) "What a tangle (world-wide) web we weave", Community College Week, Vol. 10, No. 22, pp 11-13.

[30] Elsaadani M., (2014) "Business faculty e-readiness and willingness towards online instruction", World Journal on Educational Technology, Vol. 6, No. 2, pp 151-157.

[31] Watkins R, \& Triner L., (2004) "Assessing readiness for e-learning", Performance Improvement Quarterly, Vol. 17, No. 4, pp 66-79.

[32] Hashim H, \& Tasir Z., (2014) "E-Learning Readiness: A Literature Review”, International Conference on Teaching and Learning in Computing and Engineering, IEEE.

[33] Ifinedo P, \& Davidrajuh R., (2005) "Digital divide in Europe: assessing and comparing the ereadiness of a developed and an emerging economy in the Nordic region", Electronic Government, an International Journal, Vol. 2, No. 2, pp 111-133.

[34] Gulbahar Y., (2012) "Study of Developing Scales for Assessment of the Levels of Readiness and Satisfaction of Participants in E-Learning Environments", Ankara University, Journal of Faculty of Educational Sciences, Vol. 45, No. 2, pp 119-137.

[35] Ilhan M, \& Cetin B., (2013) "The Validity and Reliability Study of the Turkish Version of an Online Learning Readiness Scale", Educational Technology Theory and Practice, Vol. 3, No. 2, pp 72-101.

[36] Saud M, Rajuddin M, Ismail S, Nordin M, Minghat A, Subari K, \& Arsat M., (2010) "ICT Application in Vocational and Technical Education and Training (VTET) Institutions in Malaysia", SEAVERN Journals, Vol. 2, No. 1, pp 213-227.

[37] Radiman N, \& Abdullah R., (2010) "ICT integration in vocational and technical education and training institutions in Brunei Darussalam", SEAVERN Journals, Vol. 2, No. 1, pp 179-199.

[38] Vinh H., (2010) ICT Applications in Tvet Institutions in Vietnam, SEAVERN Research Report 2009/2010.

[39] Robert O., (2011) "Information and communication technology awareness among technical college teachers in Benue State, Nigeria", International Journal of Vocational and Technical Education, Vol. 3, No. 6 , pp 75-80. 
International Journal of Advanced Information Technology (IJAIT) Vol. 8, No.3, June 2018

[40] Zinn S., (2009) "Readiness to adopt e-learning: pioneering a course in school librarianship education", South African Journal of Libraries and Information Science, Vol. 75, No. 2, pp 159- 169.

[41] Agboola K., (2006) "Assessing the awareness and perceptions of academic staffs in using e- learning tools for instructional delivery in a postsecondary institution: a case study", The Innovation Journal: The Public Sector Innovation Journal, Vol. 11, No. 3, pp 56-69.

[42] Volery T, \& Lord D., (2005) "Critical success factors in online education", The international Journal of Education management, Vol. 14, No. 5, pp 216-223.

[43] Watkins R, \& Corry M., (2004) E-Learning Companion: Students Guide to Online Success. New York: Houghton Mifflin.

[44] Bui T, Sankaran S, \& Sebastian I., (2003) "A framework for measuring national e-readiness", International Journal of Electronic Business, Vol. 1, No. 1, pp 3-22.

[45] Chipembele M, \& Bwalya K., (2016) “Assessing e-readiness of the Copper-belt University, Zambia: case study", The International Journal of Information and Learning Technology, Vol. 33, No. 5, pp 315332.

[46] Jinnah M, Abdullah-Al-Mamun M, Khan M, \& Hasan M., (2011) "ICT in vocational teaching/learning and research in Southeast Asian Countries: A case of Bangladesh", International Journal of Vocational and Technical Education, Vol. 3, No. 2, pp 20-28.

[47] Ghaznavi M, Keikha A, \& Yaghoubi N., (2011) "The impact of information and communication technology (ICT) on educational improvement", International Education Studies, Vol. 4, No. 2,pp 116-125.

[48] Salleh S, Jack S, Bohari Z, \& Jusoff H., (2011) "Use of information and communication technology in enhancing teaching and learning”, International Education Studies, Vol. 4, No. 2, pp 153-156.

[49] Mueller D., (1986) Measuring social attitudes: A handbook for researchers and practitioners. New York: Teachers College Press.

[50] Alharbi Y., (2002) A study of the barriers and attitudes of faculty and administrators toward implementation of online courses, Saudi Arabia (Doctoral dissertation, University of Northern Colorado, 2002), UMI Microform No. 3059974.

[51] Chen L., (2003) A study of how selected faculty and teaching staff members integrate web-based instruction in regular teaching, Unpublished doctoral dissertation, University of South Carolina.

[52] Alsaif A., (2005) The motivating and inhibiting factors affecting the use of webbased instruction at the University of Qassim in Saudi Arabia (Doctoral dissertation, Wayne State University, 2005), UMI Microform No. 3168482.

[53] Minges M., (2005) "Evaluation of e-readiness indices in Latin America and the Caribbean", Retrieved 10 August 2017 from: www.cepal.org/socinfo/publicaciones/xml/8/24228/w73.pdf .

[54] Olatokun W, \& Opesade O., (2008) “An e-readiness assessment of Nigeria's Premier University (part 1)", International Journal of Education and Development Using Information and Communication Technology, Vol. 4, No. 2, pp 16-46.

[55] Tarvid A., (2008) "Measuring the e-readiness of higher education institutions", SSE Riga Student Research Papers, Vol. 6, pp 102, Stockholm School of Economics in Riga, Riga.

[56] Alghonaim H., (2005) Attitudes, barriers and incentives of Saudi college instructors and administrators toward implementation of online instruction (Doctoral dissertation, University of Kansas, 2005), UMI Microform No. 3185123. 
International Journal of Advanced Information Technology (IJAIT) Vol. 8, No.3, June 2018

\section{AUTHORS}

\section{Dr. Mohamed Elsaadani}

As an assistant professor of Management Information Systems at Jubail University College, Dr. Elsaadani obtained his PhD degree from University of the West of England - UK in 2010. He has several research papers, as well as nationally and internationally published books in the field of IS and ICTs. Dr. Elsaadani is a professional consultant and human development trainer in the wide field of Business. He has a diverse profile with almost 24 years' experience in teaching/instructing, program developing, academic coordination, and as a senior executive in a multinational academic organizations in Egypt, Kingdom of Bahrain, and the kingdom of Saudi Arabia. Moreover, his wide experience is shared among both enterprises and academia.

\section{Dr. Saleh Alzahrani}

As an assistant professor of Computer Science at Jubail University College, Dr. Alzahrani obtained his PhD degree from De Montfort University - UK in 2010. He has several research papers published internationally. Dr. Alzahrani currently occupies the post of the Academic Deputy at Jubail University College. He has a diverse profile with almost 25 years' experience in teaching/instructing, program developing, academic coordination, and as a senior executive in a the kingdom of Saudi Arabia.
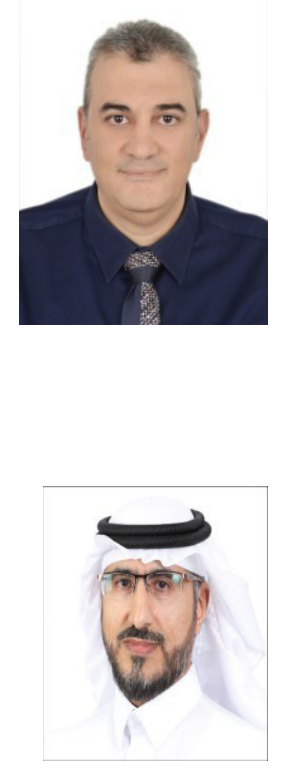